Mineralogical Journal, Vol. 6, Nos. 1/2, Pp. 69-76, Dec., 1969

\title{
THE OCCURRENCE OF STRONTIAN CHABAZITE FROM MIYANOHIRA, ÔME, TOKYO
}

\author{
KAZUSO NAKAO \\ Department of Chemistry, Faculty of Science, \\ Tokyo University of Education, Otsuka, Tokyo \\ KAZUO HARADA \\ Section of Geology, Chichibu Museum of Natural \\ History, Nogami, Saitama* \\ and \\ AKIRA KATO \\ Department of Geology, National Science Museum, \\ Ueno Park, Tokyo
}

\begin{abstract}
A chabazite containing $1.40 \%$ of SrO was found in veinlets cutting a Permian basic albitized tuff on a limestone lens at Miyanohira, Ôme, Tokyo. It is optically biaxial negative with $2 V=60^{\circ}-70^{\circ} ; \alpha=1.489, \gamma=1.491$, whereas the X-ray powder data are indexed with a hexagonal cell; $a_{0}=13.77_{9} \AA$ and $c_{0}=15.00_{0} \AA$. The most probable source of strontium in this chabazite is a calcic plagioclase contained in the tuff before albitization, which released strontium as well as calcium and formed a sodic plagioclase.
\end{abstract}

\section{Introduction}

The occurrence of chabazite in veinlets cutting a basic tuff from Miyanohira, Ôme, Tokyo, was first reported by Sakurai and Ashizawa (1953), who described the morphology and associated minerals. The present study includes the chemical analysis to detect as much as

* Present address: Central Research Laboratory, Sumitomo Metal Mining Company Ltd., Ichikawa, Chiba. 
$1.40 \%$ of $\mathrm{SrO}$, and the measurements of the unit-cell constants and some optical properties, finding the disagreement between the optical properties and the symmetry expected from the morphology and $X$-ray powder data, as often observed with chabazites. The most probable source of strontium in this chabazite was pursued and a conclusion was drawn that the host rock of veinlets originally containing strontium in the calcic plagioclase later released it with calcium upon albitization.

The authors wish to express their sincere thanks to Dr. Haruyoshi Fujimoto, Emeritus Professor of Tokyo University of Education, for his kind advice on the geological setting of the host rock, and to Dr. Mitsuo Hashimoto, National Science Museum, for his information about the basic rocks. Thanks are also due to Dr. Kin-ichi Sakurai for his advice on the associated minerals and to Prof. Kozo Nagashima, Tokyo University of Education, for his suggestions as to the chemical analyses of chabazite and the host rock of chabazite veinlets.

\section{Occurrence}

The chabazite is the principal constituent of the veinlets cutting basic tuff on a Permian limestone lens (Fujimoto, 1951) now quarried by Miyanohira Sekkai Co. The basic tuff is massive and greenish in colour with reddish gray patches of a centimeter order. The greenish part includes oligoclase laths, ophitic-textured pyroxene, and aggregates of chlorite and minor calcite. The patches are richer in oligoclase laths than the massive part with dusty interstitial materials and without pyroxene. Both greenish massive and patchy part are veined and replaced by calcite. The identified opaque minerals in both of them are ilmenite and chalcopyrite, occurring as very minute inclusions in plagioclase laths. The chabazite-bearing veinlets cutting both of them as well as calcite are of various dimensions ranging from less than one millimeter to about one 
centimeter in width and from a small seam to half a meter in extension. Generally the larger ones are drusy and contain euhedral calcite and quartz besides chabazite.

The chabazite crystals show the dominance of $r(10 \overline{1} 1)$ and the size reaches five millimeters across in maximum. In some crystals penetration twins are observed. The order of formation in the veinlets is calcite, chabazite and quartz from earlier to later.

\section{Physical and $X$-ray powder data}

The chabazite is colorless and water-clear, and void of visible inclusion. The specific gravity pycnometrically measured is 2.08 , which is within the known variation range of the specific gravity of this mineral (Winchell, 1951). It is optically biaxial and negative with $2 V=60^{\circ}-70^{\circ}, \alpha=1.489, \gamma=1.491, \gamma-\alpha=0.003(\mathrm{NaD})$.

The X-ray powder data shown in Table 1 are very close to those for normal chabazite from Jefferson County, Colorado (Gude \& Sheppard, 1966), and were indexed with $a_{0}=13.77_{9} \AA$ and $c_{0}=15.00_{0} \AA$, satisfying the extinction rule: for $h k i l, h-k+l=3 \mathrm{n}(\mathrm{n}=0,1,2, \cdots)$, and for $000 l, l=3 \mathrm{n}(\mathrm{n}=1,2,3, \cdots)$. Thus, the possible space group is one of $R \overline{3} m, R 3 m$ and $R 32$. The disagreement with the optical properties has been noticed in many chabazites of different modes of occurrence.

There are two recent reports dealing with the occurrence of strontian chabazite. One is from Chrüzlistock, Switzerland (Weibel, 1963) and the other is from Komña, Moravia (Černý \& Povondra, 1965). In Table 2 are compared some properties of strontian chabazites including those of the present one.

Since the variation of these properties in zeolites are also affected by the other chemical factors, such as the amount of sodium replacing calcium as well as the replacement of silicon by aluminum in the $\left[(\mathrm{Si}, \mathrm{Al}) \mathrm{O}_{2}\right]_{\infty}$ framework, there has been found no diagnostic physical or crystallographic properties characteristic of strontian chabazite. 
Table 1. X-ray powder data of normal and strontian chabazites.

\begin{tabular}{|c|c|c|c|c|c|c|}
\hline \multicolumn{2}{|c|}{1.} & \multicolumn{5}{|c|}{2.} \\
\hline$d(\AA)$ & $I$ & $d(\AA)$ & $I$ & Qobs. & $Q_{\text {cal }}$ & hkil \\
\hline 9.351 & 50 & 9.38 & 100 & 0.011 & 0.012 & $01 \overline{11}$ \\
\hline 6.894 & 10 & 6.89 & 10 & 0.021 & 0.021 & 1120 \\
\hline 6.384 & 5 & 6. 39 & 8 & 0.025 & 0.025 & 1012 \\
\hline 5.555 & 9 & 5.56 & 28 & 0.032 & 0.033 & 2021 \\
\hline 5.021 & 30 & 5.02 & 38 & 0.040 & 0.040 & 0003 \\
\hline 4.677 & 6 & 4. 67 & 25 & 0.046 & 0.046 & 0222 \\
\hline 4. 324 & 76 & 4. 32 & 100 & 0.053 & 0.054 & 1231 \\
\hline 4. 044 & 1 & & & & & $11 \overline{2} 3$ \\
\hline $\begin{array}{l}3.976 \\
3.870\end{array}$ & $\begin{array}{r}2 \\
28\end{array}$ & 3.99 & 8 & 0.063 & $\begin{array}{l}0.063 \\
0.067\end{array}$ & $30 \overline{3} 0$ \\
\hline $\begin{array}{l}3.870 \\
3.590\end{array}$ & $\begin{array}{l}28 \\
23\end{array}$ & $\begin{array}{l}3.89 \\
3.59\end{array}$ & 27 & $\begin{array}{l}0.066 \\
0.078\end{array}$ & $\begin{array}{l}0.067 \\
0.078\end{array}$ & 2132 \\
\hline 3. 448 & $\begin{array}{l}25 \\
13\end{array}$ & $\begin{array}{l}3.59 \\
3.45\end{array}$ & $\begin{array}{l}40 \\
17\end{array}$ & $\begin{array}{l}0.070 \\
0.084\end{array}$ & 0.084 & $\begin{array}{l}0114 \\
2240\end{array}$ \\
\hline 3. 235 & 6 & 3.24 & 14 & 0.095 & 0.096 & 3141 \\
\hline 3. 190 & 5 & 3. 18 & 12 & 0.099 & 0.099 & $20 \overline{24}$ \\
\hline 3. 033 & 2 & & & & & $13 \overline{4} 2$ \\
\hline 2.925 & 100 & 2. 927 & 100 & 0.1168 & 0.1168 & $04 \overline{1} 1$ \\
\hline 2. 890 & 30 & 2. 890 & 28 & 0.1198 & 0.1202 & 124 \\
\hline 2.842 & 3 & 2. 842 & 7 & 0.1238 & 0.1243 & 2243 \\
\hline 2. 7759 & 4 & 2.775 & 9 & 0.1299 & 1. 1300 & $40 \bar{\Phi} 0$ \\
\hline 2. 6898 & 7 & 2. 686 & 13 & 0.1386 & 0.1379 & $23 \overline{1} 1$ \\
\hline 2. 6048 & 10 & 2. 603 & 25 & 0.1476 & 0.1475 & 4150 \\
\hline 2. 5743 & 2 & 2.574 & 4 & 0.1510 & 0.1511 & $32 \div 2$ \\
\hline 2. 5067 & 11 & 2. 502 & 28 & 0.1598 & 0.1602 & 2135 \\
\hline 2. 3575 & 2 & 2. 347 & 1 & 0.1816 & 0.1812 & 1126 \\
\hline 2. 3098 & 3 & & & & & 4153 \\
\hline 2. 2996 & 4 & 2. 297 & 10 & 0.1896 & 0.1896 & $33 \overline{6} 0$ \\
\hline 2. 2767 & 1 & 2. 273 & 1 & 0.1935 & 0.1933 & $05 \div 2$ \\
\hline 2. 2333 & 1 & 2. 227 & 1 & 0.2017 & 0.2011 & $42 \bar{s} 1$ \\
\hline 2. 1233 & 2 & 2. 122 & 1 & 0.2220 & 0.2221 & $15 \overline{\hat{f}} 1$ \\
\hline 2. 1190 & 2 & & & & & 0117 \\
\hline 2.0901 & 6 & 2.087 & 17 & 0.2295 & 0.2296 & $33 \overline{53}$ \\
\hline $\begin{array}{l}2.0157 \\
1.9414\end{array}$ & $\frac{1}{1}$ & & & & & $\begin{array}{l}5054 \\
1257\end{array}$ \\
\hline 1.9110 & 3 & 1.912 & 9 & 0.2735 & 0.2739 & 5270 \\
\hline 1.8714 & 3 & $1 \cdot 870$ & 8 & 0.2861 & 0.2867 & 0555 \\
\hline 1.8074 & 8 & 1.806 & 18 & 0.3066 & $0 . \varepsilon^{064}$ & 6171 \\
\hline 1. 8047 & 8 & & & & & 3147 \\
\hline 1. 7862 & 1 & 1.786 & 1 & 0.3137 & 0.3139 & 5273 \\
\hline 1. 7710 & 2 & 1. 770 & 3 & 0.3193 & 0.3198 & $16 \overline{72}$ \\
\hline 1.7397 & 12 & & & & & 3474 \\
\hline 1. 7214 & 5 & 1. 722 & 14 & 0.3371 & 0.3371 & $44 \overline{9} 0$ \\
\hline 1. 6946 & 3 & 1. 693 & 12 & 0.3487 & 0.3486 & $53 \overline{8} 1$ \\
\hline 1. 6754 & 1 & & & & & 0009 \\
\hline $\begin{array}{l}1.6466 \\
1.6431\end{array}$ & $\begin{array}{l}1 \\
3\end{array}$ & 1.640 & 3 & 0.3719 & 0.3710 & 2681 \\
\hline 1. 5582 & 4 & 1.557 & 14 & 0.4124 & 0.4128 & $\begin{array}{l}4315 \\
60 \overline{6} \overline{6}\end{array}$ \\
\hline
\end{tabular}

1. Chabazite, North Table Mountain near Golden, Jefferson County, Colorado. Cu/Ni radiation. Diffractometer method. After Gude and Sheppard (1966).

2. Strontian chabazite, Miyanohira, Ôme, Tokyo. The present study. $\mathrm{Cu} / \mathrm{Ni}$ radiation. Diffractometer method. 
Table 2. Some physical and crystallographic properties of strontian chabazites.

\begin{tabular}{l|c|cc}
\hline & 1. & 2. & 3. \\
\hline SrO wt. $\%$ & 1.40 & 3.01 & 4.0 \\
Opt. sign & $(-)$ & $(-)$ & $(+)$ \\
Opt. angle & $60-70^{\circ}$ & $58-60^{\circ}$ & $50-60^{\circ}$ \\
& 1.489 & 1.491 & 1.487 \\
& - & - & - \\
Sp. gr. & 1.491 & 1.494 & 1.488 \\
$a_{\circ}(\AA)$ & 2.08 & 2.023 & -13.773 \\
$c_{0}(\AA)$ & $13.77_{9}$ & 13.73 & 14.994 \\
\hline
\end{tabular}

1. Strontian chabazite. Miyanohira, Ôme, Tokyo. The present study.

2. Strontian chabazite. Komňa, Moravia. After Černý and Povondra (1965).

3. Strontian chabazite. Chrüzlistock, Switzerland. After Weibel (1963).

\section{Chemical analyses of the chabazite and basic tuff}

The wet chemical analyses of hand-picked crystals of chabazite and the greenish part of basic tuff are given in Table 3 . The calculation of the former based on 12 oxygen atoms per unit leads to the following empirical formula: $\left(\mathrm{Ca}_{0.973} \mathrm{Sr}_{0.071}\left(\mathrm{Na}_{2}\right)_{0.034}\left(\mathrm{~K}_{2}\right)_{0.014}\right)_{1.092}\left(\mathrm{Al}_{0.881}\right.$ $\left.\mathrm{Fe}^{+3}{ }_{0.011} \mathrm{Si}_{4.007}\right)_{4.899} \mathrm{O}_{12} \cdot 6.628 \mathrm{H}_{2} \mathrm{O}$. This is in fairly good agreement with the ideal formula of chabazite, $\left(\mathrm{Ca}, \mathrm{Na}_{2}\right)\left[\mathrm{Al}_{2} \mathrm{Si}_{4} \mathrm{O}_{12}\right] \cdot 6 \mathrm{H}_{2} \mathrm{O}$ (Strunz, 1966).

The chemical composition of the basic tuff is not so peculiar as compared with the ordinary spilites. However, the lower silica content and higher magnesium content may be noted as a specification of this rock.

\section{Geochemical consideration and origin of strontium}

As already stated, two strontian chabazites were recently discovered; one containing $4.0 \%$ of $\mathrm{SrO}$ was found in an Alpine vein cutting syenite (Weibel, 1963), and the other containing $3.01 \%$ of $\mathrm{SrO}$ 
K. NAKao, K. HARAdA and A. Kato

Table 3. Chemical analyses of chabazite and basic tuff from Miyanohira, Ôme, Tokyo.

\begin{tabular}{l|c|c} 
& 1. & 2. \\
\hline $\mathrm{SiO}_{2}$ & 45.77 & 41.52 \\
$\mathrm{Al}_{2} \mathrm{O}_{3}$ & 18.34 & 14.28 \\
$\mathrm{Fe}_{2} \mathrm{O}_{3}$ & 0.17 & 3.90 \\
$\mathrm{FeO}$ & none & 6.94 \\
$\mathrm{CaO}$ & 10.37 & 9.57 \\
$\mathrm{SrO}$ & 1.40 & 0.14 \\
$\mathrm{BaO}$ & none & none \\
$\mathrm{MgO}$ & none & 11.12 \\
$\mathrm{MnO}$ & n.d & 0.14 \\
$\mathrm{TiO}_{2}$ & n.d & 0.70 \\
$\mathrm{P}_{2} \mathrm{O}_{5}$ & n.d & 0.07 \\
$\mathrm{~K}_{2} \mathrm{O}$ & 0.52 & 0.35 \\
$\mathrm{Na}_{2} \mathrm{O}$ & 0.81 & 2.90 \\
$\mathrm{H}_{2} \mathrm{O}(+)$ & 22.70 & 6.44 \\
$\mathrm{H}_{2} \mathrm{O}(-)$ & none & 1.82 \\
$\mathrm{CO}_{2}$ & 100.08 & 0.51 \\
\hline $\mathrm{Total}$ & & 100.42 \\
\hline
\end{tabular}

1. Strontian chabazite.

2. Basic tuff, host rock of chabazite-bearing veinlets.

in fissures of a porcelainite block probably of thermally metamorphosed argillite origin in an andesite sill at Komňa, Moravia (Č erný $\&$ Povondra, 1965). The argillite alternates with calcareous argillite beds, and the authors ascribed the possible source of strontium to the andesite and the accumulation of strontium to the hydrothermal alteration thereof.

The present strontian chabazite is different from both of them in the mode of occurrence. There are at least two geological units with the possibility to be the source of strontium: the host rock of veinlets, and the underlying limestone. The present authors believe the former to be the source of strontium from the fact that other products possibly of similar basic volcanic activity near this locality 
are also accompanied by significant concentrations of strontium and barium. The geochemical behaviours of the latter are in many respects similar to the former. At about $11 \mathrm{~km}$ westwards of Miyanohira, there is a small bedded manganese deposit called the Shiromaru mine in chert beds including a small amount of basic material, where the occurrence of cymrite, celsian and barite is recently found (Kato, unpublished), and all of these barium-bearing minerals contain strontium as the subordinate constituents replacing barium. As pointed out by Watanabe (1965), there is a close genetical relationship between bedded manganese ore deposits in older siliceous sediments and associated basic volcanic and pyroclastic materials. Accordingly, the enrichment of heavier alkalis as well as that of manganese is considered to be one of the results of basic volcanism having probably involved the analysed basic tuff. It will then be concluded that the Permian basic volcanism now known from the basic tuffs in this area is characterized by the significant concentration of heavier alkalis. The analysed basic tuff had contained strontium probably substituting calcium in the plagioclase and later suffered an albitization, which released calcium and strontium from the plagioclase.

In this respect, it is worth mentioning that the experimental study of hydrothermal alteration of synthetic basalt indicates the formation of independent strontium minerals such as celestite rather than the incorporation of strontium in clays and zeolites (Hawkins \& Roy, 1963). Their conclusion offers an expectation of the formation of sulphate ion derived from the oxidation of accessory sulphides in the original material. The present basic tuff contains very minute chalcopyrite grains in direct contact with albitized plagioclase to suggest the stable persistence of chalcopyrite during the process of albitization, provided that the chalcopyrite is of primary origin. This will then lower the probability to let the released strontium settle as the form of sulphate, and implies that the geochemical behaviour of strontium is different between the processes of albitization and the hydrothermal alteration of basic rocks as attempted 
by Hawkins \& Roy (1963), provided that the difference in chemical composition between the present basic tuff and their synthetic basalt is to be regarded to have no significant relation to the geochemical behaviour of strontium.

\section{REFERENCES}

Černý, P. \& Povondra, P. (1965). Acta Univ. Carolinae, Geol., No. 2, 163. Fujimoto, H. (1951). Kanto Region: A series of the descriptions of Japanese regional geology. Asakura Shoten, Tokyo (in Japanese).

Gude, A.J. 3rd \& Sheppard, R.A. (1966). Amer. Min., 51, 909.

Hawkins, D.B. \& Roy, R. (1963). Geochim. Cosmochim. Acta, 27, 785.

Sakurai, K. \& Ashizawa, T. (1953). Journ. Min. Soc. Japan, 1, 70 (in Japanese).

Strunz, H. (1966). Mineralogische Tabellen, Akademie Verlag, Leipzig.

Watanabe, T. (1965). Journ. Geol. Soc. Japan, 71, 332 (in Japanese).

Weibel, M. (1963). Schweiz. Miner. Petr. Mitt., 43, 361.

Winchell, A.N. (1951). Elements of optical mineralogy, 4th Ed., John Wiley \& Sons, N.Y.

Manuscript received 13 August 1969. 